\title{
THE EFFECT OF VINCRISTINE SULPHATE ON THE AXOPLASMIC FLOW OF PROTEINS IN CULTURED SYMPATHETIC NEURONS
}

\author{
J. M. ENGLAND, ${ }^{1}$ M. E. KADIN² AND M. N. GOLDSTEIN² \\ Departments of Anatomy and Pathology, Washington University School of Medicine, \\ St Louis, Missouri 631 10, U.S.A.
}

\section{SUMMARY}

The effect of vincristine sulphate on the axoplasmic flow of labelled proteins in neurites of chick embryo sympathetic neurons growing in tissue culture was studied by autoradiography. In control neurons most of the ${ }^{3} \mathrm{H}$-proteins synthesized during a 90-min pulse with a ${ }^{3} \mathrm{H}$-amino acid were localized in cell bodies. There was a diminishing gradient of labelled proteins in the neurites which was highest in portions adjacent to the cell bodies and lowest at the periphery. During a physiological chase there was a gradual increase in the amount of label in the neurites, so that after a 15 -h chase even the most peripheral portions were well labelled. This indicates that a portion of the labelled proteins synthesized in the cell bodies are transported peripherally into the neurites.

The centrifugal movement of labelled proteins in neurites was markedly decreased when cells were grown in medium containing $10 \mu \mathrm{g} / \mathrm{ml}$ vincristine sulphate. After a $15-\mathrm{h}$ chase in the presence of drug only a small amount of label was in the peripheral portion of the neurites. Treatment with vincristine did not decrease the rate of amino acid incorporation or alter the rate of protein turnover during the course of the experiment. Thus an explanation of the results based on an altered rate of total cell protein synthesis or degradation is unlikely.

The capacity of sympathetic neurons to take up and concentrate exogenous $\left[{ }^{3} \mathrm{H}\right]$ norepinephrine in their neurites was only slightly reduced by vincristine. This indicates that at least some cellular activities requiring metabolic energy are relatively unaffected by the interruption in axoplasmic flow caused by vincristine and that the mechanism by which vincristine interferes with axoplasmic flow does not involve general cellular toxicity.

The major morphological differences between control and vincristine-treated neurons were the absence of microtubules and the presence of crystal-like structures within the cells. The relationship between the effect of vincristine on the axoplasmic flow of proteins and the arrangement of the microtubule system is discussed.

\section{INTRODUCTION}

Numerous studies have supported the concept proposed by Weiss \& Hiscoe (1948) that cellular constituents in neurons, including proteins, are transported down the axon from the cell body to the terminal (for reviews see Barondes \& Samson, I967; Weiss, 1967). Recent investigations have shown that local application to nerve trunks of drugs which bind to microtubule protein (e.g. colchicine (Borisy \& Taylor, 1967)

1 Present address: Division of Biology, California Institute of Technology, Pasadena, California 9 I rog, U.S.A.

- Present address: Department of Clinical Pathology and Laboratory Medicine, University of California Medical Center, San Francisco, California 941 22, U.S.A.

3 To whom requests for reprints should be directed. 
or vinblastine (Marantz, Ventilla \& Shelanski, I969)) can block the axoplasmic transport of labelled proteins in vertebrate optic nerve (Karlsson \& Sjöstrand, 1969), sciatic nerve (James, Bray, Morgan \& Austin, I970) and crayfish nerve cord (Fernandez, Burton \& Samson, 1971).

In the present work, isolated sympathetic neurons growing in tissue culture were used to study the direct effect of vincristine sulphate on neuronal functions in the absence of the complexities found in the intact animal.

The purpose of this investigation was to determine the effect of vincristine sulphate on (I) the transport of proteins in neurites, (2) the ultrastructure of the microtubule system, and (3) the capacity of neurites to concentrate exogenous norepinephrine in a tissue culture system of functionally differentiated sympathetic neurons.

\section{MATERIALS AND METHODS}

\section{Conditions of cell culture}

Thoracolumbar sympathetic ganglia from I I-day-old chick embryos were dissociated with trypsin, and explanted either on collagen-coated coverslips in 35-mm plastic Petri dishes or directly on the plastic substrate of these dishes (England \& Goldstein, 1969). The cells were grown for one to two weeks in medium $199,30 \%$ calf serum and 20 units $/ \mathrm{ml}$ mouse nerve growth factor (Levi-Montalcini \& Booker, I960). The cells growing on collagen were used for autoradiography and electron microscopy and those growing on plastic for scintillation counting.

\section{Radioactive labelling conditions}

Prior to labelling the cells with a ${ }^{3} \mathrm{H}$-amino acid the growth medium was replaced with a medium consisting of Hanks's balanced salt solution (BSS), $30 \%$ calf serum and 20 units $/ \mathrm{ml}$ nerve growth factor, and incubated for $2 \mathrm{~h}$ at $37^{\circ} \mathrm{C}$. Vincristine sulphate $(1 \circ \mu \mathrm{g} / \mathrm{ml})$ was added to the experimental cultures during the last $30 \mathrm{~min}$ of this period. Control and experimental cultures were then pulse labelled with 5 or $20 \mu \mathrm{Ci} / \mathrm{ml}$ of $\mathrm{DL}-\left[4,5^{3} \mathrm{H}\right]$ leucine (specific activity $5 \mathrm{Ci} / \mathrm{mm}$ ) or L- $\left[4,5^{-3} \mathrm{H}\right]$ tyrosine (specific activity 4 o or $50.5 \mathrm{Ci} / \mathrm{mm}$ ) for $90 \mathrm{~min}$ at $37{ }^{\circ} \mathrm{C}$. At the end of this period, cultures were thoroughly rinsed with Hanks's BSS and prepared for either autoradiography or scintillation counting. Other control and experimental cultures were chased in complete growth medium (containing unlabelled L-leucine, $5 \times 10^{-4} \mathrm{M}$, or L-tyrosine, $3 \times$ $\mathrm{IO}^{-4} \mathrm{M}$ ) with and without vincristine sulphate ( $\left.10 \mu \mathrm{g} / \mathrm{ml}\right)$ for varying periods of time.

To determine the effect of cycloheximide (an effective inhibitor of extramitochondrial protein synthesis (Ennis \& Lubin, 1964)) on the incorporation of ${ }^{3} \mathrm{H}$-amino acids, cells were preincubated for $90 \mathrm{~min}$ in Hanks's BSS, $30 \%$ calf serum and 20 units $/ \mathrm{ml}$ nerve growth factor, then exposed to $50 \mu \mathrm{g} / \mathrm{ml}$ cycloheximide for $30 \mathrm{~min}$ and pulse labelled with io $\mu \mathrm{Ci} / \mathrm{ml}\left[{ }^{3} \mathrm{H}\right]$ leucine or $\left[{ }^{3} \mathrm{H}\right]-$ tyrosine for $60 \mathrm{~min}$ in the presence of the drug. These cells and drug-free controls were prepared for autoradiography or scintillation counting.

To determine the effect of vincristine on the uptake of norepinephrine, experimental cultures were incubated for various periods of time in growth medium containing $10 \mu \mathrm{g} / \mathrm{ml}$ vincristine sulphate. Vincristine-treated and control cultures were pulse labelled for $60 \mathrm{~min}$ in medium I 99 containing $\mathrm{I}$ or $5 \mu \mathrm{Ci} / \mathrm{ml} \mathrm{DL}-\left[7^{3} \mathrm{H}\right]$ norepinephrine (specific activity $7 \cdot 1 \mathrm{Ci} / \mathrm{mM}$ ) and prepared for autoradiography or scintillation counting.

\section{Autoradiographic method}

Cultures labelled with ${ }^{3} \mathrm{H}$-amino acids were fixed in either $3 \%$ glutaraldehyde, in Hanks's BSS or in Bouin's fluid at $4{ }^{\circ} \mathrm{C}$ for $18 \mathrm{~h}$. All cultures labelled with $\left[{ }^{8} \mathrm{H}\right]$ norepinephrine were fixed with $3 \%$ glutaraldehyde. Cells fixed in Bouin's fluid were thoroughly rinsed in $70 \%$ ethanol and then hydrated; cultures fixed with glutaraldehyde were washed thoroughly with distilled water. The cultures were coated with Kodak AR-Io stripping film as previously 
described (Goldstein, 1967). These preparations were exposed in light-tight boxes for 7 days at room temperature, developed and stained with $0.02 \%$ toluidine blue in $0.15 \mathrm{M}(\mathrm{pH} 6.0)$ phosphate buffer.

\section{Scintillation counting methods}

Cultures were mechanically removed from the plastic substrate, frozen on a metal plate in liquid nitrogen and lyophilized at $-40{ }^{\circ} \mathrm{C}$. The dried samples were weighed on a quartz fibre balance (Lowry, I94I). Samples labelled with a ${ }^{3} \mathrm{H}$-amino acid were placed in $3 \mathrm{ml}$ of $5 \%$ trichloroacetic acid (TCA) $+\mathrm{r} \mathrm{mg} / \mathrm{ml}$ of the corresponding unlabelled amino acid at $4{ }^{\circ} \mathrm{C}$ for $\mathrm{I} \mathrm{h}$. These samples were heated to $85{ }^{\circ} \mathrm{C}$ for $30 \mathrm{~min}$, cooled, and washed with 3 volumes, Io $\mathrm{ml}$ each, of cold $5 \%$ TCA on a membrane filter $(0.45 \mu \mathrm{m}$ pore size, Gelman Instrument Co., Ann Arbor, Michigan) under a slight vacuum. The TCA-insoluble material on the filter was moistened with $0.1 \mathrm{ml}$ distilled water and solubilized in $1 \mathrm{ml}$ Soluene-100 (Packard Instrument Corp.). Dried samples labelled with $\left[{ }^{3} \mathrm{H}\right]$ norepinephrine were moistened with $\mathrm{o} \cdot \mathrm{I} \mathrm{ml}$ distilled water and solubilized with $0.5 \mathrm{ml}$ Soluene-100.

When the TCA precipitate or tissue was completely solubilized, ro $\mathrm{ml}$ cf scintillation fluid (6.37 g 2,5-diphenyloxazole (PPO) + $0.63 \mathrm{~g}$ I,4-bis-2(4-methyl-5-phenyloxazol)benzene (dimethyl POPOP) in toluene) was added, and samples were counted for a time sufficient to yield $\pm \mathrm{I} \%$ standard deviation in counting accuracy.

\section{Electron-microscopic technique}

Cultures were fixed in $3 \%$ glutaraldehyde in Hanks's BSS $\left(\mathrm{pH} 7 \cdot 0\right.$ ) at $4{ }^{\circ} \mathrm{C}$ for $2-4 \mathrm{~h}$. Areas of interest were cut from the culture, washed in Hanks's BSS at $4{ }^{\circ} \mathrm{C}$ for $2-24 \mathrm{~h}$, and postfixed in $\mathrm{I} \% \mathrm{OsO}_{4}$ in Hanks's BSS at room temperature for $\mathrm{I}$ h. Two drops of formalin were added after the first $30 \mathrm{~min}$ of $\mathrm{OsO}_{4}$ postfixation. The tissue was dehydrated in a graded series of ethanols followed by propylene oxide and embedded in Epon resin. Thin sections were collected on uncoated grids and stained with lead citrate (Venable \& Coggeshall, i 965). The sections were observed and photographed with an $\mathrm{RCA}$ EMU $-3 \mathrm{H}$ microscope.

\section{RESULTS}

In the following experiments the autoradiographic graining which resulted from labelling sympathetic ganglion cultures with $\left[{ }^{3} \mathrm{H}\right]$ leucine or $\left[{ }^{3} \mathrm{H}\right]$ tyrosine was almost completely eliminated by $50 \mu \mathrm{g} / \mathrm{ml}$ cycloheximide. Under the same conditions of cycloheximide treatment the incorporation of $\left[{ }^{3} \mathrm{H}\right]$ tyrosine into hot TCA-precipitable material, i.e. protein, was inhibited about $91 \%$. These data indicate that the autoradiographic grains in this material are predominantly due to ${ }^{3} \mathrm{H}$-amino acid residues which have been incorporated into proteins and not due to free amino acid molecules adventitiously bound to the cells.

\section{Movement of ${ }^{3} \mathrm{H}$-proteins within neurites}

Immediately after a 90 -min pulse with $\left[{ }^{3} \mathrm{H}\right]$ leucine or $\left[{ }^{3} \mathrm{H}\right]$ tyrosine the autoradiographic grains were predominantly localized over neuronal cell bodies. A small amount of graining was present over the neurites adjacent to the aggregated cell bodies (Fig. 3) and only a very few grains were detected over their periphery (Fig. 4). The satellite cells and fibroblasts in these cultures were labelled over both nucleus and cytoplasm. After a 7 -h chase period there was a general increase in the number of grains over the neurites, including their peripheral portions (Fig. 5). Fifteen hours following the pulse the entire network of neurites including the finest collaterals was labelled (Fig. 6). 


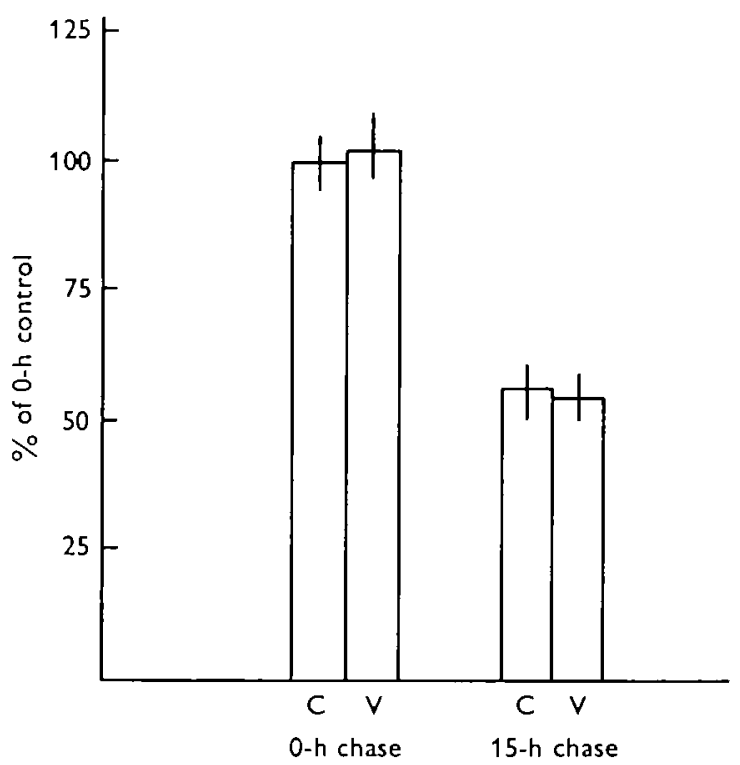

Fig. I. Effect of vincristine sulphate on the incorporation of $\left[{ }^{3} \mathrm{H}\right]$ tyrosine and turnover of incorporated label. Cultures were incubated for $2 \mathrm{~h}$ in a medium containing $70 \%$ Hanks's BSS $+30 \%$ calf serum +20 units $/ \mathrm{ml}$ nerve growth factor and then pulsed with $5 \mu \mathrm{Ci} / \mathrm{ml}$ (specific activity $50.5 \mathrm{Ci} / \mathrm{mm}$ ) $\left[{ }^{3} \mathrm{H}\right]$ tyrosine for $90 \mathrm{~min}$ at $37^{\circ} \mathrm{C}$ and chased for $\mathrm{I}_{5} \mathrm{~h}$. Vincristine-treated cultures were exposed to $10 \mu \mathrm{g} / \mathrm{ml}$ vincristine sulphate $30 \mathrm{~min}$ prior to the pulse and throughout the pulse and chase periods. The radioactivity incorporated into hot TCA-precipitable material was measured as described in Materials and Methods. Amount of label was expressed as a per cent of that in the o-h control cultures. Each point represents the mean and range of 4-6 cultures. $\mathrm{C}$, control; $\mathrm{V}$, treated with vincristine sulphate.

This gradual increase in graining over the peripheral neurites during the chase period indicated that a portion of the labelled proteins which had been synthesized in the cell bodies were transported peripherally into neurites.

The centrifugal movement of ${ }^{3} \mathrm{H}$-proteins in neurites was markedly decreased in neurons which had been treated with ro $\mu \mathrm{g} / \mathrm{ml}$ vincristine sulphate. However, immediately after the ${ }^{3} \mathrm{H}$-amino acid pulse the distribution and density of graining over the cell bodies was similar to that in controls. After a $5^{\text {-h }}$ chase in medium containing vincristine the neurites in the vincristine-treated cultures were less densely labelled than those in the controls (Figs. 7,8 ). After a 15 -h chase this difference became more striking; there were very few grains over the neurites in drug-treated cultures (Fig. 9) but those in control cultures were densely labelled (Fig. Io). In control and vincristinetreated material identical autoradiographic results were obtained whether the cultures were labelled with $\left[{ }^{3} \mathrm{H}\right]$ leucine and fixed with glutaraldehyde, or labelled with $\left[{ }^{3} \mathrm{H}\right]-$ tyrosine and fixed with Bouin's fluid.

\section{Rate of synthesis and degradation of labelled proteins}

There was little difference in the incorporation of $\left[{ }^{3} \mathrm{H}\right]$ tyrosine into hot TCAprecipitable material in control and vincristine-treated cultures which were pulsed 


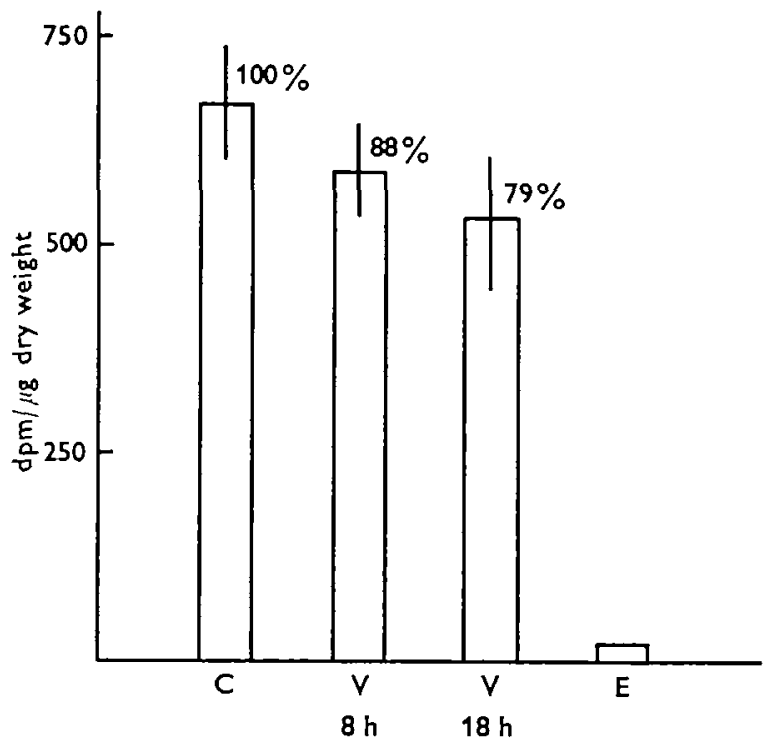

Fig. 2. Effect of vincristine sulphate on the accumulation of $\left[{ }^{3} \mathrm{H}\right]$ norepinephrine label. Cultures were exposed to $10 \mu \mathrm{g} / \mathrm{ml}$ ] vincristine sulphate in growth medium for 8I $8 \mathrm{~h}$ and then pulsed for $60 \mathrm{~min}$ at $37^{\circ} \mathrm{C}$ with I $\mu \mathrm{Ci}(25 \mathrm{ng}) / \mathrm{ml}\left[{ }^{3} \mathrm{H}\right]$ norepinephrine in medium 199. Each point represents the mean and range of the specific activities of 4 cultures. 'Equilibrium' represents a calculated tissue-medium equilibrium of $\left[{ }^{8} \mathrm{H}\right]$ norepinephrine. $\mathrm{dpm}=$ disintegrations per minute. $\mathrm{C}$, control; $\mathrm{V}$, treated with vincristine sulphate; $\mathrm{E}$, equilibrium.

and chased under conditions identical to those used in the autoradiographic experiments. Despite the fact that vincristine interfered with the movement of labelled protein toward the periphery of the neurites, the labelled proteins remaining in treated cultures after a 15 -h chase were not less than in controls; in both groups it was about $55 \%$ of that found in cultures immediately after the $90 \cdot$ min pulse with $\left[{ }^{3} \mathrm{H}\right]$ tyrosine (Fig. I).

\section{Effect of vincristine on $\left[{ }^{3} \mathrm{H}\right]$ norepinephrine uptake}

The capacity of sympathetic ganglion cultures to take up and concentrate exogenous $\left[{ }^{3} \mathrm{H}\right]$ norepinephrine was only slightly reduced by exposure to $10 \mu \mathrm{g} / \mathrm{ml}$ vincristine. Cultures grown with vincristine for 8 and $\mathrm{i} 8 \mathrm{~h}$ accumulated about 88 and $79 \%$ respectively of the label found in untreated controls. In addition, drug-treated neurons established and maintained a cellular concentration of norepinephrine which was many times greater than the calculated tissue-medium equilibrium (Fig. 2).

The $\left[{ }^{3} \mathrm{H}\right]$ norepinephrine label was concentrated in the neuronal processes of cells which had been exposed to vincristine for $\mathrm{I} 8 \mathrm{~h}$ (Fig. II). The density of graining was only slightly less than that in untreated controls (Fig. 12). The $\left[{ }^{3} \mathrm{H}\right]$ norepinephrine label was restricted to neurons in both control and drug-treated cultures. Graining was not observed in satellite or fibroblastic cells. In both control and experimental cultures the neurites were much more densely labelled than the cell bodies. 


\section{Fine structure of sympathetic neurons treated with vincristine}

In the cell bodies and neurites of control sympathetic neurons the cytoplasmic organelles are surrounded by a myriad of microtubules ( $\sim 25 \mathrm{~nm}$ diameter) and neurofilaments ( $\sim$ IO $\mathrm{nm}$ diameter). The major morphological differences between drugtreated and normal neurons were the absence of microtubules and presence of crystallike structures in the cell bodies and neurites of neurons exposed to vincristine (Figs. I3-I 5, cf. I6). Otherwise the neurons showed very few signs of generalized deterioration even after $17 \mathrm{~h}$ of exposure to $10 \mu \mathrm{g} / \mathrm{ml}$ vincristine sulphate. The plasma and nuclear membranes, free and membrane-associated polysomes, neurofilaments and mitochondria remained intact with little distortion. A small percentage of mitochondria, however, showed myelin-type degeneration. The crystalloids in the cell bodies and neurites were devoid of other cellular organelles and were composed of a closely packed array of subunits, about $20-25 \mathrm{~nm}$ in diameter. These inclusions were seen throughout the cytoplasm of the cell bodies and often had a diameter of $2-3 \mu \mathrm{m}$ in cross-section (Fig. 13). They frequently occluded the lumina of neurites and displaced dense- and lucid-core vesicles and mitochondria to a position subjacent to the plasma membrane. Within neurites, the longitudinal axis of the crystalloids was parallel to that of the neurite. Despite the absence of microtubules, the proportion of neurofilaments and dense- and lucid-core vesicles was similar to that found in controls (Figs. I 4, I5). Clusters of dense-core vesicles were observed in the varicosities of terminal neurites of the sympathetic neurons in control (Fig. 16) and vincristine-treated cells (Fig. I4).

\section{DISCUSSION}

The progressive appearance of labelled proteins in peripheral neurites during a physiological chase is interpreted as a qualitative demonstration of the transport of recently synthesized proteins from the cell body into the neurites of cultured sympathetic neurons. The possibility that the progressive appearance of label in neurites represented local amino acid incorporation within the neurite, rather than proximodistal flow, is unlikely on several grounds. First, typical ribosomes or polysomes were not observed in the neurites; of course, this does not rule out mitochondrial protein synthesis. Secondly, the proximo-distal gradient of label was suggestive of flow and not local synthesis. Finally, the relatively high concentration of unlabelled amino acid in the chase medium would effectively compete with the labelled amino acid in the cellular pools and virtually eliminate incorporation during the chase period. These observations confirm the axoplasmic flow concept of Weiss \& Hiscoe (I948) and the work of others who demonstrated a proximo-distal flow of labelled proteins in neurites of intact animals (e.g. Droz \& Leblond, 1962; Lasek, 1968; McEwen \& Grafstein, 1968; Sjöstrand \& Karlsson, 1969).

The centrifugal movement of labelled proteins in neurites is markedly decreased by vincristine sulphate. This work and studies on mouse brain (Agustin \& Creasey, 1967) demonstrate that total protein synthesis is not significantly affected by vin- 
cristine treatment. The present work also shows the amount of labelled protein lost after a $15^{-h}$ chase is similar in vincristine-treated and control cultures. Therefore, it is unlikely that vincristine prevents the appearance of labelled protein in neurites by simply depressing total protein synthesis or enhancing protein turnover. It is also unlikely that the effect of vincristine is due to a decrease in the rate of protein synthesis resulting from long exposure to the drug, since the axoplasmic transport of slow (Peterson, Hurwitz \& Lindsay, 1967) and rapidly moving proteins (McEwen \& Grafstein, I968) is not inhibited by long treatment with cycloheximide.

Sympathetic neurons growing in tissue culture take up and concentrate exogenous catecholamines by an active metabolic process which is temperature-dependent and sensitive to ouabain, an inhibitor of ATPase activity (England \& Goldstein, 1969, and unpublished data). The observation that vincristine-treated neurons are only slightly less effective in concentrating exogenous norepinephrine indicates that processes requiring metabolic energy continue to occur in drug-treated neurons and that the effect of vincristine on axoplasmic flow is due to a specific cellular lesion(s) rather than general toxicity. In addition, the minimal perturbation of the catecholamineuptake system after interruption of the axoplasmic flow of proteins suggests that the most labile protein components of the uptake system are relatively stable. This is consistent with the observation that when protein synthesis is blocked for $20 \mathrm{~h}$ with I $50 \mu \mathrm{g} / \mathrm{ml}$ cycloheximide, the ability of sympathetic neurons to concentrate exogenous catecholamines is diminished by only about $30 \%$ (England \& Goldstein, unpublished data).

The ultrastructural alterations - that is, microtubular dissolution and crystalloid formation - which occur in neurons exposed to Vinca alkaloids (Schochet, Lampert \& Earle, 1968) suggest that vincristine affects the axoplasmic flow of proteins as a direct result of its well documented reaction with microtubules and microtubular protein (Bensch, Marantz, Wisniewski \& Shelanski, 1969; Marantz, Ventilla \& Shelanski, 1969; Olmsted et al. 1970), although a causal relationship has not been established in this work.

Vincristine treatment causes no ultrastructural alterations to the $\sim$ Io-nm neurofilaments in cultured sympathetic neurons. In addition, neurons in the crayfish nerve cord, in which both rapid and slow axoplasmic flow occur normally, contain no detectable filaments (Fernandez et al. I97I). Thus it seems unlikely that neurofilaments are involved in axoplasmic transport.

There are several possible mechanisms by which vincristine-induced alterations to the microtubular system could impede axoplasmic flow. The microtubular crystalloids could occlude the lumen of neurites and physically block flow. Electron micregraphs show that most smaller processes are completely filled by crystalloids, although some larger processes are only partially occluded.

The microtubular subunit, tubulin, is transported to brain nerve endings where it constitutes approximately $28 \%$ of the soluble protein of these endings (Feit, Dutton, Barondes \& Shelanski, 1971). It is possible that newly synthesized tubulin may be precipitated in situ by vincristine, thus preventing its transport. However, the relationship between tubulin transport and the effect of vincristine on axoplasmic flow remains 
to be determined. Finally, microtubules or their ancillary structures may play a functional role in transport such that a disruption of their normal orientation would alter their functional capacity (Fernandez et al. 1971).

This work was supported by a research grant from the U.S. Public Health Service (CAI0755) to M.N.G. and by a research fellowship from the National Institute of General Medical Sciences (4-FoI-GM-4I 039) to J.M.E.

\section{REFERENCES}

Agustin, B. M. \& Creasey, W. A. (1967). Vinca alkaloids and the synthesis of RNA in mouse brain. Nature, Lond. 215, 965-966.

Barondes, S. H. \& Samson, F. E. (I 967). Axoplasmic transport. Neurosciences Res. Prog. Bull. 5, 365-370.

Bensch, K., Marantz, R., Wisniewski, H. \& Shelanski, M. (1969). Induction in vitro of microtubular crystals by vinca alkaloids. Science, N.Y. r65, 495-496.

Borisy, G. C. \& TAYlor, E. U. (I967). The mechanism of action of colchicine. 7 . Cell Biol. 34, 525-533.

Droz, B. \& Leblond, C. P. (I962). Migration of proteins along the axons of the sciatic nerve. Science, N.Y. 137, 1047-1048.

England, J. M. \& Goldstein, M. N. (1969). The uptake and localization of catecholamines in chick embryo sympathetic neurons in tissue culture. F. Cell Sci. 4, 677-691.

EnNis, H. \& Lubin, M. (1964). Cycloheximide: aspects of inhibition of protein synthesis in mammalian cells. Science, N.Y. 146, $1474-1476$.

Feit, H., Dutton, G. R., Barondes, S. H. \& Shelanski, M. (1971). Microtubule protein. 7. Cell Biol. 5I, $138-147$.

Fernandez, H. L., Burton, P. R. \& Samson, F. E. (1971). Axoplasmic transport in the crayfish nerve cord. F. Cell Biol. 5I, I76-192.

Goldstein, M. N. (1967). Incorporation and release of ${ }^{3} \mathrm{H}$-catecholamines by cultured fetal human sympathetic nerve cell and neuroblastoma cells. Proc. Soc. exp. Biol. Med. 125, $993-996$.

James, K. C., Bray, J. J., Morgan, I. G. \& Austin, L. (1970). The effect of colchicine on the transport of axonal protein in the chicken. Biochem. $\mathcal{F}$. I17, 767-771.

Karlsson, J. O. \& Sjöstrand, J. (I969). The effect of colchicine on the axonal transport of protein in the optic nerve and tract of the rabbit. Brain Res. 13, 6r7-6ra.

LASEK, R. (I968). Axoplasmic transport in cat dorsal root ganglion cells : as studied with [ $\left.{ }^{2} \mathrm{H}\right] \mathrm{L}-$ leucine. Brain Res. 7, 360-377.

Levi-Montalcini, R. \& Booker, B. (I960). Excessive growth of sympathetic ganglia evoked by a protein isolated from mouse salivary glands. Proc. natn. Acad. Sci. U.S.A. 46, 373-384.

Lowry, O. H. (1941). A quartz fiber balance. f. biol. Chem. 140, 183-189.

McEwen, B. S. \& Grafsteln, B. (1968). Fast and slow components in axonal transport of protein. F. Cell Biol. 38, 494-508.

Marantz, R., Ventilla, M. \& SHELANSKI, M. L. (1 969). Vinblastine-induced precipitation of microtubule protein. Science, N.Y. 165, 498-499.

Olmsted, J. B., Carlson, K., Klebe, R., Ruddle, F. \& Rosenbaum, J. (1970). Isolation of microtubule protein from cultured mouse neuroblastoma cells. Proc. natn. Acad. Sci. U.S.A. 65, I 29-136.

Peterson, R. P., Hurwitz, R. M. \& Lindsay, R. (1967). Migration of axonal protein: absence of a protein concentration gradient and effect of inhibition of protein synthesis. Expl Brain Res. 4, $138-145$.

Schochet, S. S., Lampert, P. W. \& Earle, K. M. (1968). Neuronal changes induced by intrathecal vincristine sulfate. F. Neuropath. exp. Neurol. 27, 645-658.

SjÖstrand, J. \& Karlsson, J.-O. (I969). Axoplasmic transport in the optic nerve and tract of the rabbit: a biochemical and autoradiographic study. $\mathcal{F}$. Neurochem. 16, 833-844. 
Venable, J. \& Coggeshall, R. (1965). A simplified lead citrate stain for use in electron microscopy. 7. Cell Biol. 25, 407-408.

Weiss, P. (1967). Neuronal dynamics. Neurosciences Res. Prog. Bull. 5, 371-400.

Weiss, P. \& Hiscoe, H. B. (I948). Experiments on the mechanism of nerve growth. f. exp. Zool. 107, 315-395.

(Received I7 Fuly 1972) 
Figs. $3^{-12}$ are autoradiographs of cultures of dissociated sympathetic neurons from I I-day-old chick embryos.

Figs. 3-6. Progressive appearance of labelled protein in peripheral neurites. All cultures were pulsed with $20 \mu \mathrm{Ci} / \mathrm{ml}\left[{ }^{3} \mathrm{H}\right]$ leucine and chased for various intervals in a medium containing $5 \times 10^{-4} \mathrm{M}$ unlabelled L-leucine. Glutaraldehyde fixation, 14 days in vitro.

NoTE: similar results were obtained with cultures labelled with $\left[{ }^{3} \mathrm{H}\right]$ tyrosine and fixed with Bouin's fluid.

Fig. 3. Neurites immediately surrounding an aggregate of cell bodies. 0 -h chase; culture fixed immediately after pulse.

Fig. 4. Terminal neurites at periphery of culture. o-h chase; culture fixed immediately after pulse.

Fig. 5. Terminal neurites at periphery of culture. 7-h chase.

Fig. 6. Terminal neurites at periphery of culture. 15 -h chase. 

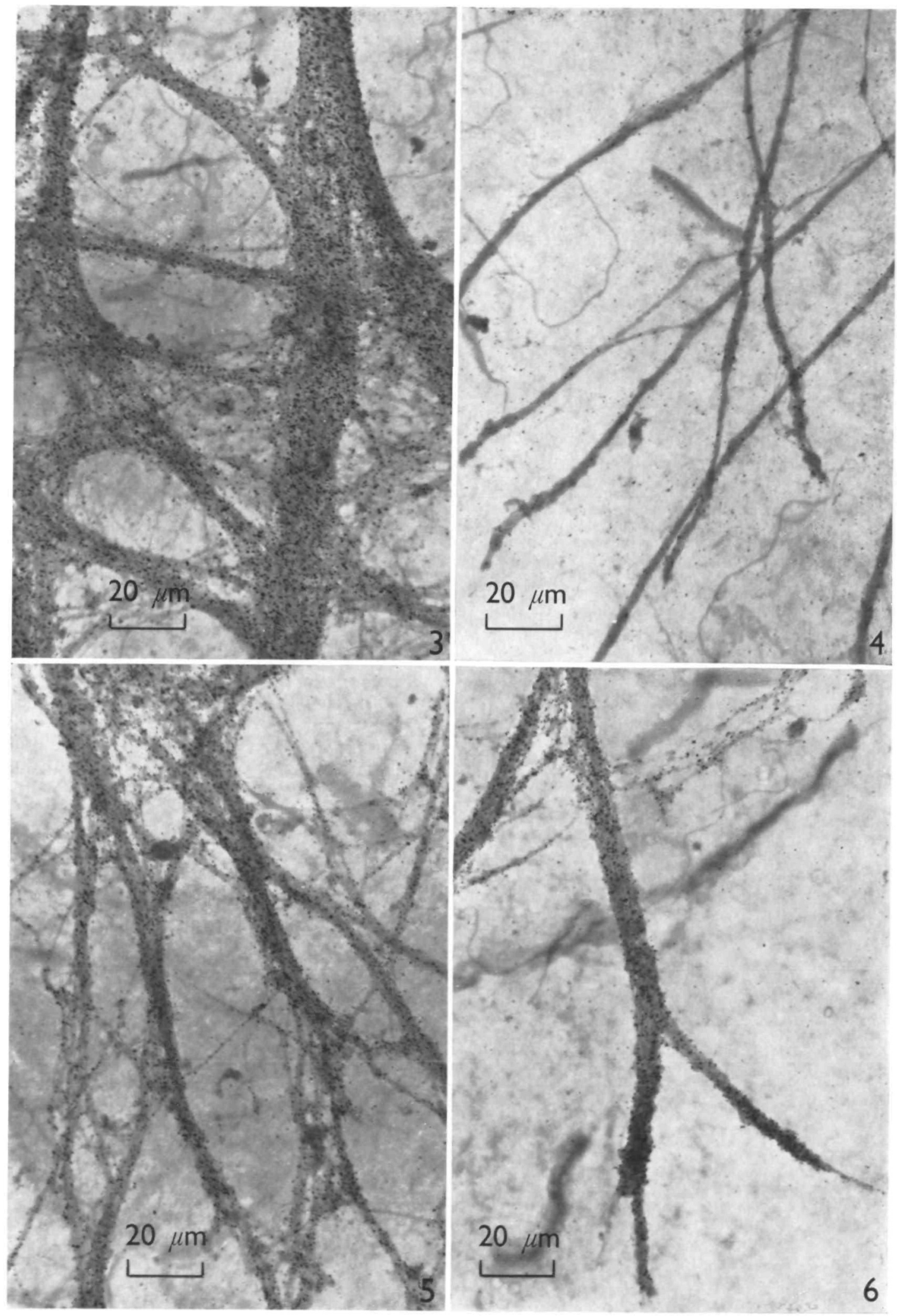
Figs. 7-10. Effect of vincristine on the appearance of labelled protein in peripheral neurites. All cultures pulsed with $20 \mu \mathrm{Ci} / \mathrm{ml}\left[{ }^{3} \mathrm{H}\right]$ tyrosine and fixed in Bouin's solution. Chase medium contained $3 \times \mathrm{rO}^{-4} \mathrm{M}$ unlabelled L-tyrosine. 12 days in vitro.

Note: similar results were obtained with cultures labelled with ['H]leucine and fixed with glutaraldehyde.

Fig. 7. Neurites in culture treated with ro $\mu \mathrm{g} / \mathrm{ml}$ vincristine sulphate for $7 \mathrm{~h} .5-\mathrm{h}$ chase following pulse.

Fig. 8. Neurites in control culture. 5-h chase following pulse.

Fig. 9. Neurites in culture treated with $10 \mu \mathrm{g} / \mathrm{ml}$ vincristine sulphate for $17 \mathrm{~h}$. I $5-\mathrm{h}$ chase following pulse.

Fig. 1o. Neurites in control culture. I5-h chase following pulse. 


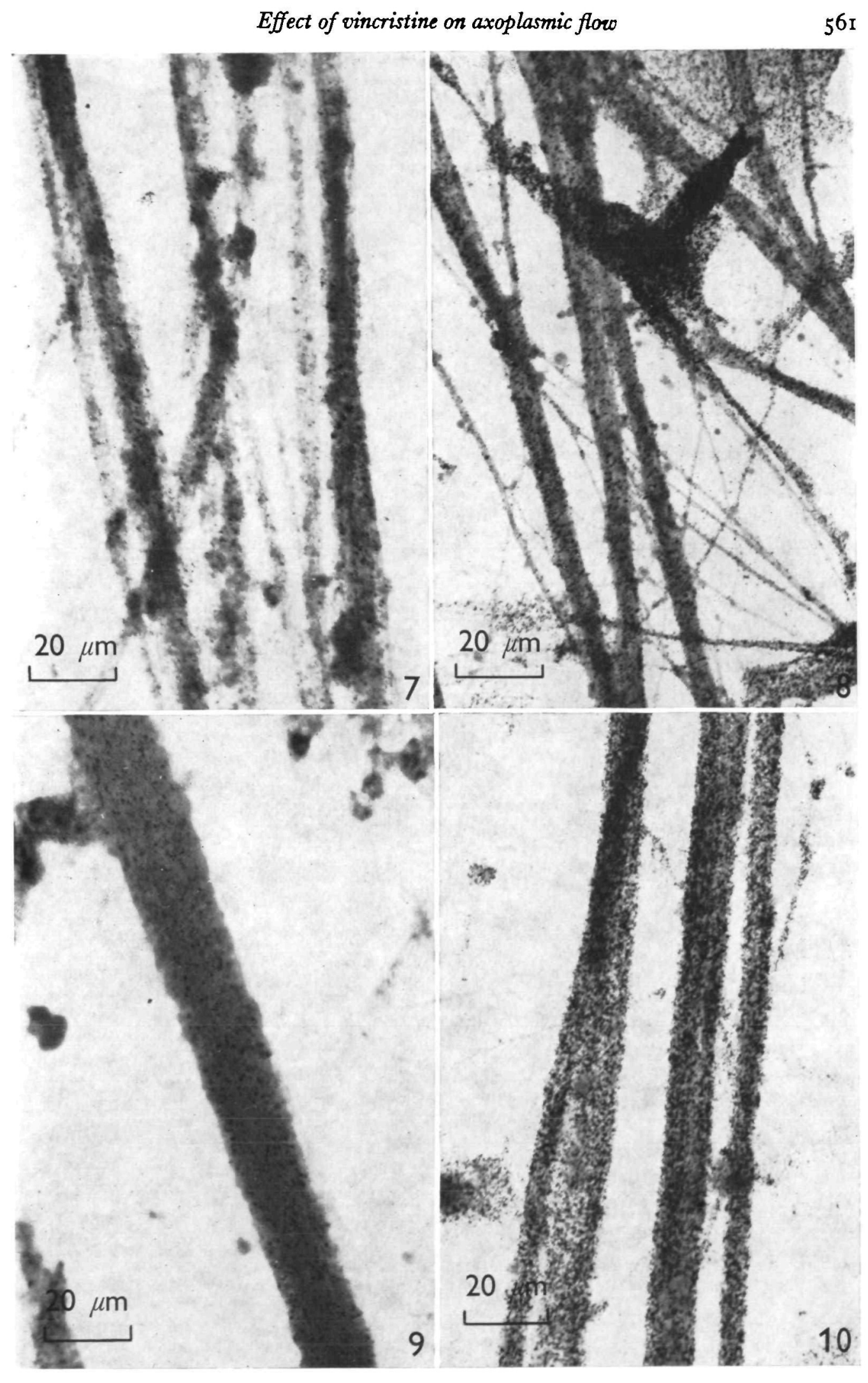


Figs. I I, I 2. Effect of vincristine on $\left[{ }^{3} \mathrm{H}\right]$ norepinephrine accumulation. Glutaraldehyde fixation. 12 days in vitro.

Fig. I I. Control culture pulsed with $5 \mu \mathrm{Ci}(125 \mathrm{ng}) / \mathrm{ml}\left[{ }^{3} \mathrm{H}\right]$ norepinephrine for $60 \mathrm{~min}$.

Fig. 12. Vincristine-treated culture exposed to $10 \mu \mathrm{g} / \mathrm{ml}$ vincristine sulphate for I $8 \mathrm{~h}$ then pulsed with $5 \mu \mathrm{Ci}(\mathrm{I} 25 \mathrm{ng}) / \mathrm{ml}\left[{ }^{3} \mathrm{H}\right]$ norepinephrine for $60 \mathrm{~min}$.

Figs. 13-16 are electron micrographs of sympathetic neurons grown in tissue culture for 14 days.

Fig. 13. Neuronal cell body in a culture exposed to $10 \mu \mathrm{g} / \mathrm{ml}$ vincristine sulphate for I $7 \mathrm{~h}$. The large crystal-like structure $(c)$ and the absence of microtubules distinguish drug-treated cells from controls. With the exception of a few damaged mitochondria $(m)$, other cellular organelles are not noticeably disrupted. Numerous neurofilaments and a few dense-core vesicles are in the cytoplasm. 

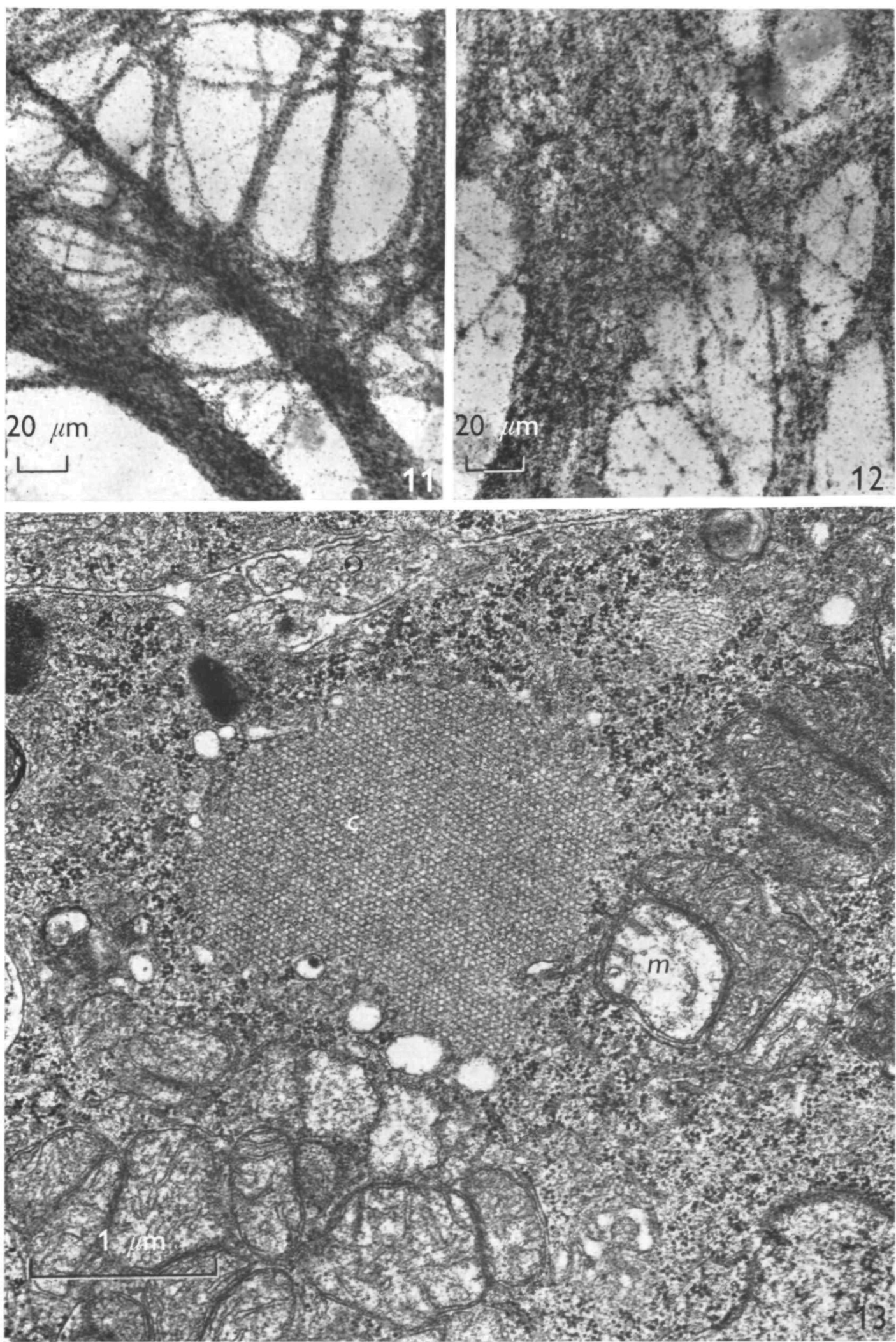
Figs. I4, 15. Cross- and longitudinal sections, respectively, of neurites in a culture exposed to $10 \mu \mathrm{g} / \mathrm{ml}$ vincristine sulphate for $\mathrm{I} 7 \mathrm{~h}$. Microtubules are not present. Crystal-like structures almost completely fill the lumina of the neurites and displace the mitochondria, vesicles and clusters of neurofilaments to the periphery. Terminal neurites, as seen in controls, contain accumulations of dense and lucid core vesicles (arrow).

Fig. 16. Terminal and preterminal neurites of control culture. Note the parallel orientation of microtubules and neurofilaments along the longitudinal axis of the preterminal neurites (arrow). There are many dense and lucid core vesicles within the varicosities along the terminal neurites (double arrow) and relatively few in the non-varicose preterminal regions of the neurites (arrow). 
Effect of vincristine on axoplasmic flow

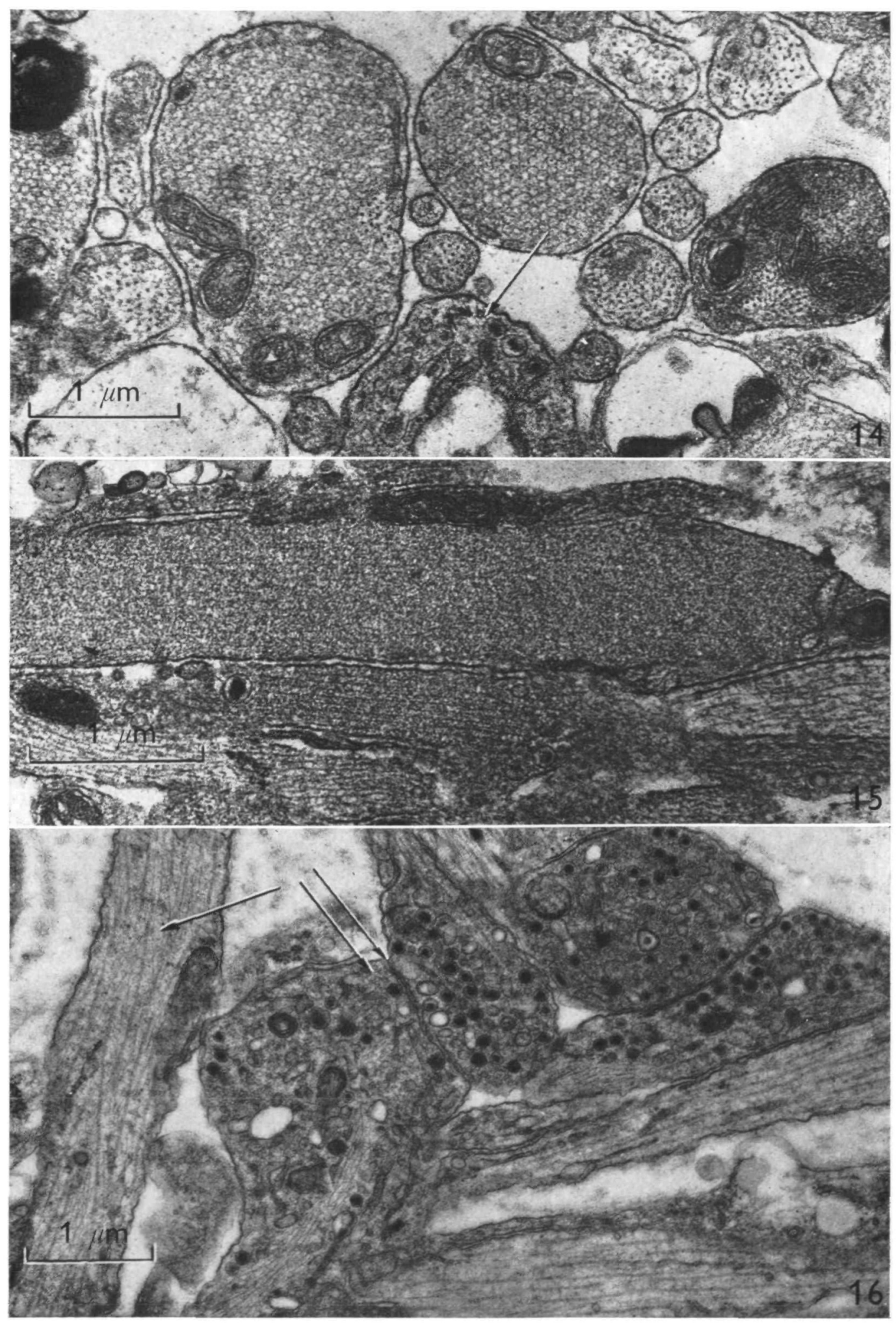


